\title{
Momentum, October 2003
}

Population Council

Follow this and additional works at: https://knowledgecommons.popcouncil.org/ series_newsletters_momentum How does access to this work benefit you? Let us know!

\section{Recommended Citation}

"Momentum, October 2003," newsletter. New York: Population Council. 

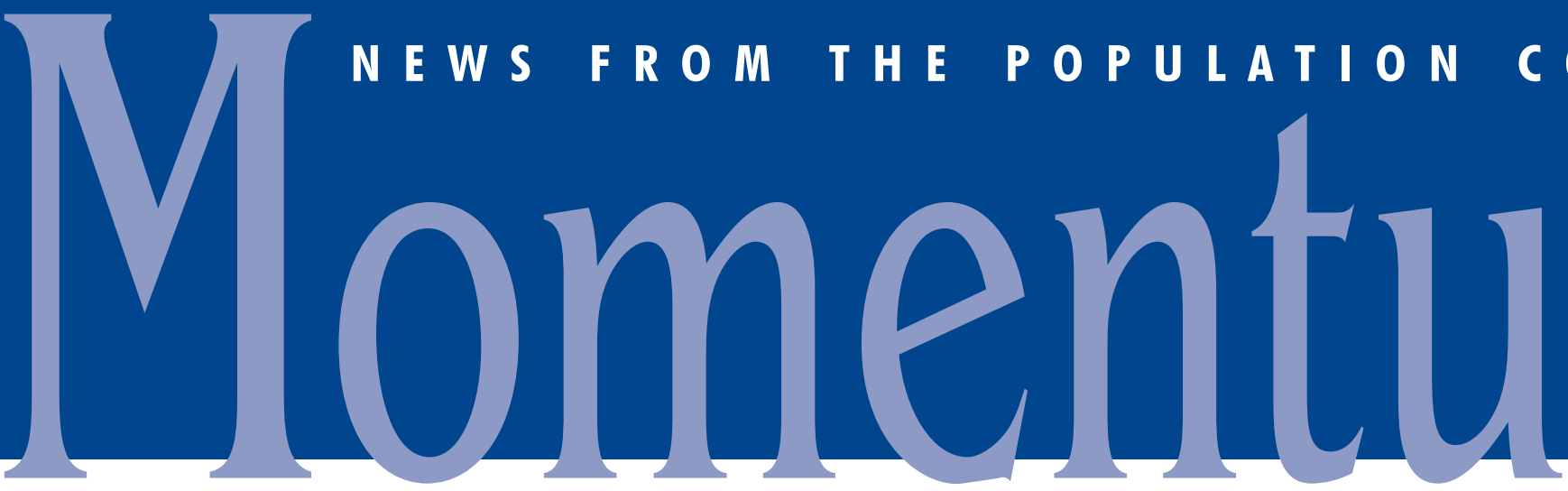

C O U N C I L

OCTOBER 20003

\section{"Historic" survey of Pakistani youth published}

Three high-level officials of the government of Pakistan joined Population Council researchers on July 24 for the release of Adolescents and Youth in Pakistan 2001-2002, a national survey conducted by the Council in cooperation with Pakistan's Federal Bureau of Statistics. The first of its kind in Pakistan, the survey analyzes interviews in which more than 8,000 young people were asked about their attitudes toward school, work, and marriage. Called "historic" by the United Nations-based IRIN News, the survey field work and report took 16 months to complete.

Pakistan's Minister for Finance and Economic Affairs, Shaukat Aziz, officiated at the ceremony. The Federal Secretaries of Population Welfare and of Minorities, Culture, and Youth Affairs also spoke, as did representatives of the UK Department for International Development and UNICEF Pakistan. (The last two organizations had joined The Rockefeller Foundation and the United Nations Population Fund in funding the survey.)

Aziz noted that the survey findings "will facilitate the government, civil society, and the private sector in formulation of their programs on youth for education and for their careers." One-sixth of Pakistan's population is between the ages of 15 and 24. Among the survey's findings: No more than 39 percent of girls living in rural areas have ever been to school, yet marriage ages are rising, resulting in a longer time interval between puberty and marriage.

More than 250 media and development professionals attended the event, which was

continued on page 5

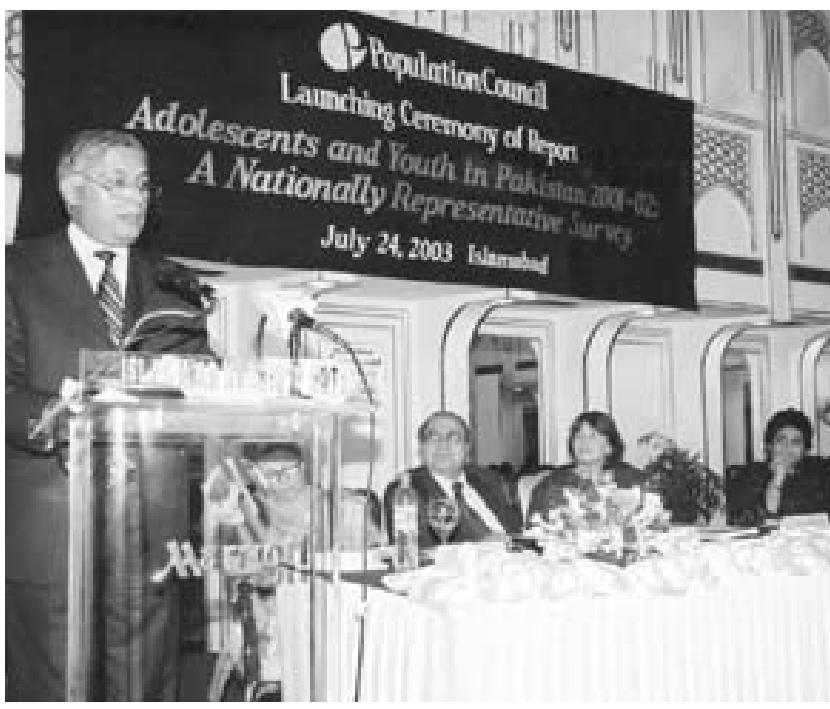

Minister for Finance and Economic Affairs Shaukat Aziz speaks to an audience of more than 250 reporters, development professionals, and dignitaries at the launching ceremony for Adolescents and Youth in Pakistan 2001-2002.

\section{Adolescents:}

\section{One person in five}

Over 1.2 billion young people ages 15 to 24-20 percent of humanity - are now making the transition from childhood to adulthood. Six years ago, the Population Council embarked on an intensive study of adolescence in developing countries. Field-based projects are now in progress in Bangladesh, Burkina Faso, Egypt, Guatemala, India, Kenya, Mali, Pakistan, South Africa, and Vietnam. Issues being studied include education and livelihood opportunities, health interventions, savings and micro-credit plans, and ways of encouraging adolescents, particularly girls, to stay in school.

\section{Working at the cellular and molecular level}

A half dozen small, equipment-packed rooms form the "CellCore" of the Population Council's Center for Biomedical Research (CBR) on the campus of The Rockefeller University. Shorthand for "Cell Biology and Flow Cytometry Core," the CellCore provides technical services for CBR scientists, postdoctoral trainees, and research staff. Scientists from as far away as China, India, and Japan and as close as The Rockefeller University and Weill Medical College benefit through collaborations with Council scientists. Facility director Patricia L. Morris notes, "Our ultimate purpose is to foster and support high-quality research, and our challenge is to provide researchers intensive, hands-on training in the use of sterile techniques, and daily support services for cell culture-based studies." The Council purchased a state-of-the-art cell sorter and added "flow cytometry" (see page 5) to the list of technical services the CellCore offers. Smaller than most major household appliances, the fluorescence- activated cell sorter (FACS) employs multiple lasers to characterize cells based on their DNA, specific cell markers, and distinct biomolecules. For example, FACS sorting can select rare subpopulations of breast or dendritic immune cells, or sperm from millions of freshly isolated human cells. Cells can be sorted into enriched populations with the exact recognition molecules (receptors) needed for further analyses in a specific progestin experiment on breast or endometrial cells, or microbicide efficacy studies.

CellCore researchers and trainees investigate issues ranging from reproductive health and dysfunction, immunology, and toxicology to preclinical drug evaluations using living cells. To demonstrate that a particular, predictable mechanism is at work, the rules of scientific research require that results be reproducible. In cell-based studies, this means using either carefully characterized cells that proliferate in a controlled manner (e.g., normal self-renewing cells such as skin) or an uncontrolled manner 


\section{Peter J. Donaldson returns to direct Council's largest division}

Peter J. Donaldson joined the Population Council as vice president and director of its International Programs Division in May 2003. Donaldson comes to the Council after serving as president of the Population Reference Bureau for nine years, but he definitely is not "new" to the organization. His first postdoctoral position was at the Council, conducting research in Thailand and South Korea in the mid-1970s. After working for other institutions for over a decade, Donaldson was back from 1989 to 1994 as regional director for South and East Asia.

"I am very enthusiastic about my new position," says Donaldson. "The Population Council is an important international institution. Each time I have worked at the Council, I have been impressed by the quality of the

\section{Obstetrics in Cairo}

continued from back cover

Other findings include important discoveries regarding the pattern of administration of antihemorrhage drugs, inconsistencies in recording progress of labor on medical charts, and the relationships between physicians and patients.

Barbara L. Ibrahim, Council regional director for West Asia and North Africa, reports that the administration and staff of El-Galaa Hospital had an immediate, positive response to the study findings. "We succeeded in our goal to actively engage management and staff in thinking about clinical practice, and they are eager to institute needed improvements the study brought to light."

Karima Khalil, one of the study's authors, adds, "The study has generated considerable interest in Egypt and abroad. The findings have important implications for the training of new physicians, particularly in developing countries. We are now disseminating our methodologies, data collection tools, and other findings throughout Egypt and the region to advance the quality of obstetric care for women anticipating normal labor."

The research team consisted of Mohamed Cherine of El-Galaa Hospital, Nevine Hassanein of John Snow International, Amr Elnoury and Lamia Mohsen of Cairo University, Hania Sholkamy of the American University in Cairo, Nabil Younis of Al-Azhar University Faculty of Medicine, and Miral Breebaart and Zeinab Farahat of the Population Council, and was coordinated by Karima Khalil of the Population Council. The study was funded by the Ford Foundation, the American University in Cairo's Social Research Center, and the Population Council. research and the ability of the staff," he added. Donaldson has also served as the director of development and government relations at Family Health International and as director of the Committee on Population of the National Research Council. He is the author, co-author, or editor of six books and more than 60 scientific and popular articles on population, development, Asian affairs, and other issues. Donaldson earned a B.A. from Fordham University and a Ph.D. in sociology from Brown University.

\section{Pakistan survey}

continued from front cover

covered on the front pages of Pakistan's newspapers. According to The News (Islamabad), the speakers "commended the efforts of the Population Council for compiling a comprehensive report on an important issue." The Pakistani officials also termed the report "useful for the researchers and policy-makers, and called upon the government to incorporate its recommendations in the formulation of youth policy in the country."

The Council was represented by Barbara Ibrahim, regional director for West Asia and North Africa; Zeba Sathar, country director for Pakistan; and Cynthia B. Lloyd, director of social science research in New York.

\section{CellCore}

continued from front cover

(e.g., prostate or breast cancer cells), or cells that do not divide once they are isolated from living tissue (e.g., sperm). All of these experimental models require the highest levels of sterile techniques and standardization of protocols. Strict anti-contamination procedures are used in CBR's two room-HEPA-filtered CellCore culture laboratories, which are accessed through clean anterooms to eliminate ambient corridor contaminants. Powerful ceiling air filters in all rooms create a level of cleanliness equal to a surgical operating suite. In the "cell line" room, more than 300 lineages of immortalized cells, originally derived from various human and animal cancers and normal tissues, are protected from contaminants. Hundreds of vials of such immortalized cell lines are held in a repository, banked in suspended animation while frozen below $-160^{\circ} \mathrm{C}$ until particular cells are needed for an investigator's experiment. Thus a

\section{Flow cytometry}

The FACS Calibur flow cytometry system is used to measure properties of single cells revealed by their light scatter in suspension and fluorescence; its dual lasers perform four fluorescence analyses simultaneously. The particular applications of this technology provided by the CellCore are responsive to the needs of users, and include cell cycle analysis, identification of specific immune cell populations, developmental and stem cell biology, measurement of physiological responses in testicular cells, quantitation of cell death, DNA content analysis, and characterization of cells with particular molecular markers.

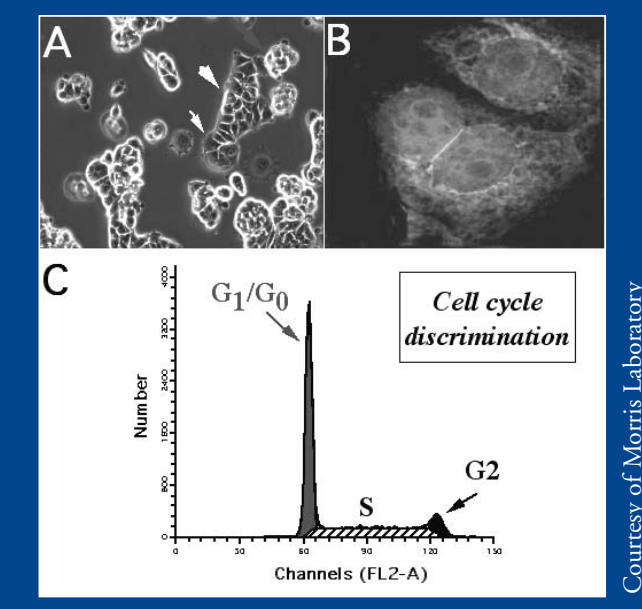

Human Breast Cancer Cells

Immortalized breast adenocarcinoma cells were maintained in defined growth culture conditions. Mammary epithelial-like cell clusters are illustrated (see arrows, light microscopy, Panel A). Cells viewed at a subcellular level by differential-interference-contrast microscopy show three adjacent breast cells, each with a large round nucleus with chromatin stain, surrounded by extensive mitochondria (Panel B). Cell cycle FACS analysis of progestin receptor positive breast cells categorizes those in a DNA synthesis phase compared to those in growth phases (see $S$ versus G, Panel C).

researcher can return years later and continue work using the same line of cells, ruling out any variations in results due to cellular aging or genetic drifts in characteristics of these cells over time. The second "primary culture" room is dedicated to experiments that isolate specialized cells from animal and human tissue biopsy materials.

Morris notes, "Having this centralized, specialized Cell Biology and Flow Cytometry Core facility enables Council investigators to minimize the use of animals in their experiments, ensures highest-quality, sterile culture-related reagents and supplies for their cell-based molecular biology work, reduces weekly expenses for associated materials and support personnel, and facilitates ongoing and new projects with its extensive cell repository and state-of-the-art, managed quality control and instrumentation." 


\section{Protecting newborns from HIV infection}

By 1998, the need to provide health workers with practical guidance on how to help HIVpositive mothers prevent transmission of the virus to their babies was clear. Every year more than 700,000 infants worldwide contract HIV through mother-to-child transmission.

To address this virtual pandemic within a pandemic, the Horizons program ${ }^{\dagger}$ joined forces with the Kenya PMCT ${ }^{\dagger+}$ Project, UNICEF, and the Regional AIDS Training Network to create the PMCT Training Curriculum. USAID funded this collaborative initiative. The PMCT training guide was published in 2002 following several years of testing, feedback, and revision. The ten-day curriculum covers epidemiology and prevention strategies, maternal nutrition and preparation for breastfeeding, child nutrition, counseling skills for prevention of mother-to-child transmission, and community involvement. It is being disseminated free of charge around the globe as a CD-ROM and as a downloadable file from the Council's Web site at www.popcouncil.org/ pdfs/horizons/pmcttc/pmcttc.pdf. The manual has been used by the Network for AIDS Research in East and Southern Africa (NARESA), Family Health International, and the Centers for Disease Control and Prevention to train health workers in PMCT services. As the main implementing partner of the Kenya PMCT Project, NARESA has trained more than 600 health care workers through its participation in the development of the curriculum. In addition, the UN Interagency Task Force on PMTCT has selected the Kenya curriculum to train leaders for workshops throughout the region, and NARESA and Horizons led the first international workshop using the manual.

Health workers, community leaders,

organizations for people living with HIVIAIDS, and governmental and nongovernmental program managers who are gaining hands-on experience with the curriculum are being encouraged to share their observations and suggestions for inclusion in future editions of the training manual.

${ }^{\dagger}$ Horizons is a research collaboration funded by the United States Agency for International Development (USAID) and directed by the Population Council with six partners: the International Center for Research on Women, the International HIVIAIDS Alliance, the Program for Appropriate Technology in Health, Tulane University, Family Health International, and Johns Hopkins University. More information about Horizons is available at www.popcouncil.org/horizons.

\section{Breastfeeding and HIV: No easy answers}

An estimated 35 to 40 percent of infants born to HIV-positive women contract the virus during pregnancy, delivery, or breastfeeding if no action is taken to prevent mother-to-child transmission. Yet, breastfeeding is known to give an infant an optimal nutritional start in life-the incidence of infant mortality from diarrhea, malnutrition, and respiratory infection is greatly reduced for children who are breastfed.

HIV-positive mothers must make difficult choices about how best to care for their newborns. Antiretroviral drug therapy for mothers and infants, cesarean section deliveries, and the use of infant formula rather than breast milk can significantly reduce the likelihood of HIV transmission. These options are proving successful in reducing transmission in the world's richer countries. However, these options are not yet viable alternatives for most HIV-positive mothers in sub-Saharan Africa, where as many as 90 percent of new infections among infants worldwide occurred in 2001 and mother-to-child transmission continues to be a major factor in the increase of HIV infection among children.

Simple and cost-effective intervention strategies for reducing transmission that can be integrated into existing health clinic settings are helping to stem mother-to-child transmission. UNAIDS, UNICEF, and WHO advise that health-care managers conduct a thorough investigation into local infant feeding options and weigh the relative risks specific to each local context. Research suggests that there are safer ways to breastfeed, namely through exclusive breastfeeding. The chances for transmission are greater the longer children of HIV-positive mothers breastfeed and if children receive solid food in combination with their mother's milk. It is not clear exactly why this is the case-whether solid food causes small tears in the gastrointestinal tract and thus enhances transmission of HIV or if breastfeeding on a more sporadic basis increases the likelihood of infections in the breast, which then can increase the viral load in the mother and thus transmission to the baby.

A recent study conducted by Horizons researchers and partners in Ndola, Zambia, showed that mothers-to-be who participated in counseling about HIV transmission during their pregnancies made better-informed choices and maintained practices - including breastfeeding exclusively and weaning their children after four to six months - that reduce transmission of HIV.

For more information, see "Breastfeeding Education Helps PMTCT” at www.popcouncil.org/horizons/articles/ ndolapmtct.html. "Empowering communities to respond to HIV," the final report on the Ndola Demonstration Project, can be downloaded from www.popcouncil.org/pdfs/ horizons/ndolafnl.pdf. Copies of the report are available free of charge by e-mailing horizons@pcdc.org.

\section{A population scientist's odyssey}

Under the Banyan Tree:

A Population Scientist's Odyssey

by Sheldon J. Segal

Oxford University Press

Sheldon J. Segal recognized the serious consequences of rapid population growth in developing countries early in his career and built an impressive record of accomplishment over the past 50 years. He served as the founding director of both the Population Council's Center for Biomedical Research and The Rockefeller Foundation's Population Sciences program. He has authored over 250 publications in the fields of embryology, endocrinology, the biology of reproduction and contraceptive development, and family planning. Collaborating in a 1999 Oxford University Press publication, Segal asked the intriguing question, Is Menstruation Obsolete?

In Under the Banyan Tree, published by Oxford in January 2003, Segal chronicles the doubling of the world's population in the last 40 years and the growth of government-sponsored family planning programs in less-developed countries. He offers a personal perspective on the importance of rigorous science and research to further the progress that has been made toward improving human well-being and points to the significant population challenges to be met in the coming decades. Commenting on having stepped outside of the laboratory to talk citizen to citizen in Under the Banyan Tree, Segal notes, "I have written this book with the hope that it will enhance public interest and enlighten population dialogue."

Senior editor Laragh Gollogly of the venerable British medical journal The Lancet writes of Segal that not only is he "an enlightening and entertaining witness to history, he was instrumental in making it." Gollogly continues, "Most non-governmental organizations claim to promote change for the better; the Population Council actually has hard evidence of having changed the lives and expectations of hundreds of millions of people."

Segal currently serves as the Council's

Distinguished Scientist and as chairman of its Institutional Review Board. A prolific author, he is about to release Hormone Use in Menopause and Male Andropause: A Choice for Women and $M e n$, co-authored with Dr. Luigi Mastroianni. The book analyzes why men and women experience midlife changes and what can be done to control the symptoms. 


\section{On the ground in sub-Saharan Africa}

Population Council president Linda G. Martin, Peter J. Donaldson, vice president and director of the Council's International Programs Division (see page 5), and Ayorinde Ajayi, regional director for sub-Saharan Africa, travelled together for three weeks in Africa this June, meeting with researchers and high-level government officials. Discussions focused on the Council's efforts to provide the scientific basis for cost-effective policies and programs to improve the well-being and health of people in some of the poorest countries in the world. Given the daunting population issues facing Africa, the Council is working to ensure that its research, technical assistance, and capacity-building activities are helping policymakers and program managers make the best use of their limited resources.

A highlight of the Ghana leg of the journey, during which Council board chairman Rodney B. Wagner joined the contingent, was a meeting with His Excellency John A. Kufuor, who was elected president of Ghana in December 2000. The visit, which was reported on the front page of The Ghanaian Times as well as on Accra television and radio, provided the opportunity for Wagner and Martin to thank President Kufuor for his support of the Population Council in the past year. (In 2002, the Council consolidated its regional headquarters in Accra, the capital of Ghana. Previously, activities of the Council's seven offices in sub-Saharan Africa had been managed from Dakar, Senegal, and Nairobi, Kenya.) President Kufuor thanked the Council on behalf of the people of Ghana and said that "the government [would] do everything possible to make the Council's operations in Ghana smooth."

The substance of the meeting focused on reporting to Mr. Kufuor about the group's visit to Nkwanta in the Volta Region on the border with Togo. Nkwanta is a key site in the plan to replicate nationwide lessons learned from the Council's decade-long research project in Navrongo in northern Ghana. That experiment,

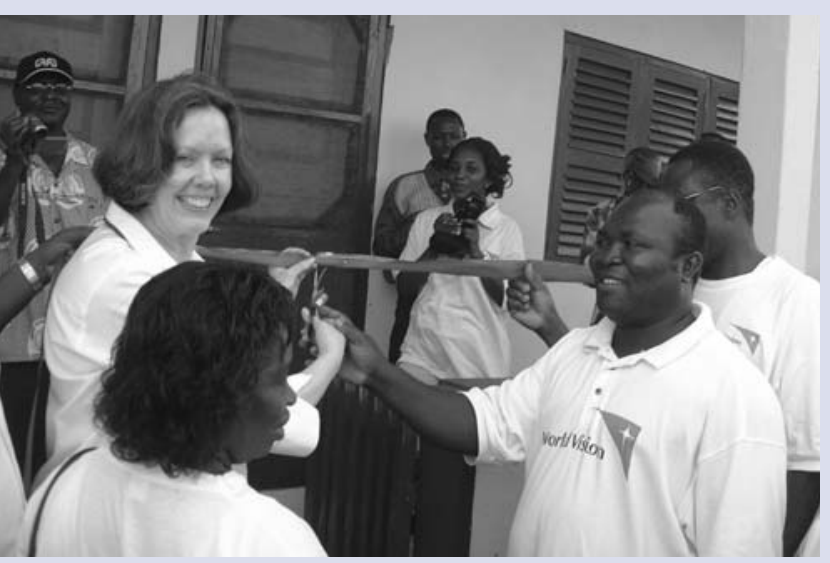

Linda Martin of the Population Council and WorldVision's Nicholas Ahadjie share the honors at the opening of the Azua Community Health Center in Ghana. conducted in collaboration with the Ministry of Health's Navrongo Health Research Centre, has demonstrated that child survival and reproductive health could be substantially improved by mobilizing community resources and by relocating government nurses from centralized clinics to local communities. Application of these concepts and interventions in Nkwanta has resulted in health services being provided by ten community health nurses to over 40 percent of the district's more than 187,000 people-a population that previously had relied on one doctor and his staff at the district hospital.

While in Nkwanta, Council representatives met with district leaders, community health workers, and local residents whom the tribal chiefs

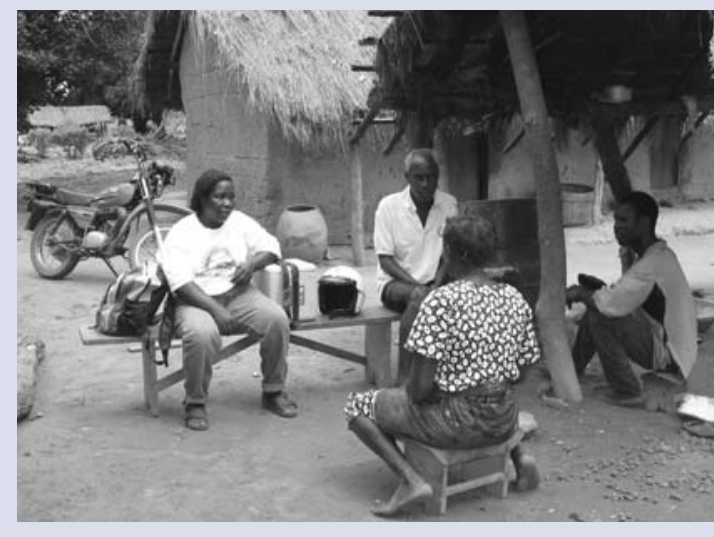

An Nkwanta community health nurse visits a compound via motorcycle to demonstrate how to prepare a nutritious dish recommended for malnourished children. surrounding AIDS, a topic of ongoing Population Council research." It is estimated that over one-fifth of the 15-to-49-year-old population in South Africa is HIV-positive.

During the final stop in Kenya, the group had the opportunity to visit a project aimed at improving opportunities for young people to earn a decent living. In Kenya, 44 percent of the population is under the age of 15 , and education and jobs are quite limited for most. The project, which focuses on girls and boys ages 16 to 22 in the Nairobi slum of Eastlands, is being implemented by K-Rep, the Kenyan micro-credit financing organization. Council researchers are evaluating whether the approach of combining small loans with training in business and life skills is a cost-effective and elders had brought together for a community durbar (a gathering convened for motivational speechmaking and entertainment). They were joined by representatives of WorldVision, a faithbased organization that works with the world's poorest children and families, in dedicating the Azua Community Health Center-a modest structure built by members of the Azua community in which a government nurse will live and care for the community. WorldVision provided physical resources to build the health center; Council researchers were key partners in designing the package of services to improve health care.

The next stop was South Africa, where Martin, Donaldson, and Ajayi met with colleagues at the University of Cape Town and the Medical University of Southern Africa (MEDUNSA) who helped conduct the Population Council's expanded safety trials for Carraguard ${ }^{\circledR}$, the Council's candidate microbicide to prevent the sexual transmission of HIV. Both institutions are working with the Council on preparations for the large efficacy trial that the Council hopes to start in 2004, with support from USAID and the Bill and Melinda Gates Foundation, among others. Along with Nono Simelela, chief director of the HIV/AIDS Directorate of the National Department of Health, Martin dedicated a clinic in Soshanguve township near Pretoria, where MEDUNSA will conduct one arm of the Council's microbicide clinical trial. Commenting on the ceremony, Martin said,

"Most notable for me were public testimonials by a group of young people who are HIV-positive about how the epidemic has changed their lives and about the need to reduce the fear and denial way to provide a better future for the young people of Kenya and elsewhere.

The group also met with the Honorable Charity K. Ngilu, minister for health, who is part of the administration of President Emilio Mwai Kibaki, elected in December 2002. Ms. Ngilu thanked the Council for its research in Kenya and discussed ways in which the Council can continue to assist Kenya's government and people. The Council has been active in Kenya since 1965 when a Council team helped the government prepare its first population policy. Of particular interest to Ngilu and her staff is the possibility of scaling up nationwide a pilot program to reduce mater-
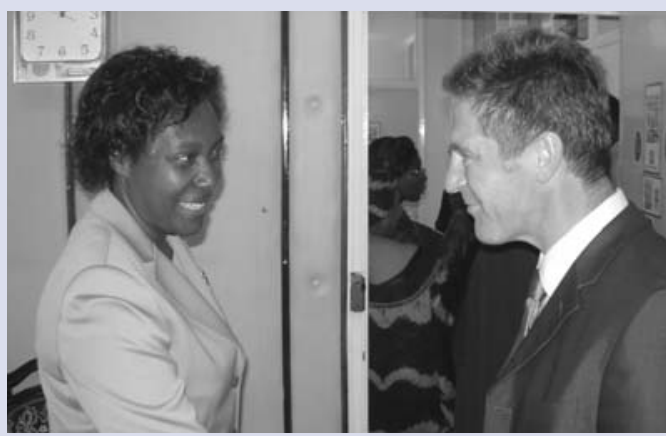

Ian D. Askew, country representative for Kenya, is greeted by the Honorable Charity K. Ngilu, Kenya's Minister for Health.

nal mortality through expanded access to antenatal services, attended deliveries, and obstetric referrals for pregnancy complications. Council researchers have been evaluating the pilot in western Kenya with support from the UK Department for International Development. continued on page 4 


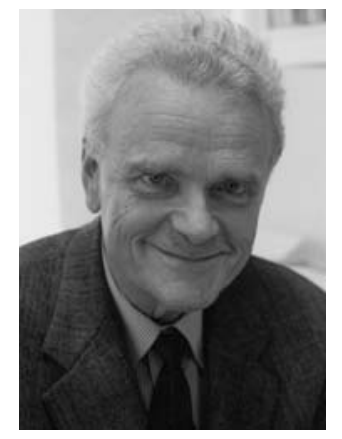

Council scholar honored

Distinguished Scholar Paul Demeny has been awarded two major honors this year: the title "Laureate" from the International Union for the Scientific Study of Population (IUSSP) and the Olivia Schieffelin Nordberg Award. The IUSSP award recognizes "outstanding contribu- tions to the advancement of the population sciences and distinguished service rendered to ... the profession." The Nordberg Award is given every two years for excellence in writing and editing in the population sciences.

A former Council vice president, Demeny is founder and editor of Population and Development Review. As the intellectual force behind this peer-reviewed journal for nearly three decades, Demeny has influenced the shape and content of population research, promoted a productive interchange with other disciplines, and raised the level and cogency of debate on population policy.

\section{New members elected to the board of trustees}

Prominent attorney Mark A. Walker and finance expert Robert B. Millard have been elected to the Population Council's board of trustees. Millard previously served as a trustee from 1993 to 2002. The board now includes 17 men and women from nine countries-Ethiopia, Germany, India, Japan, Jordan, Kenya, Mexico, Sweden, and the United States.

"It is an honor to have Mark Walker on our board and to welcome Bob Millard as a returning member," said Council president Linda G. Martin. "Mark and Bob share with other members of the board a commitment to excellence and objectivity in furthering the Population Council's research in order to help developing countries address the critical population issues they face."
A partner in the law firm of Cleary, Gottlieb, Steen, and Hamilton since 1975, Walker advises the governments of Indonesia, Korea, Mexico, and other countries on debt management and infrastructure finance. He also has advised private-sector debtors and creditors in negotiating complex international restructurings. He holds an LL.B. degree from Yale Law School.

Millard, managing director of the investment banking firm Lehman Brothers since 1983, has expertise in world financial markets. He heads Lehman Brothers' Trading \& Investments Group and the Merchant Banking Group and has served on several nonprofit boards, including those of the Massachusetts Institute of Technology and New School University. Millard holds an M.B.A. from Harvard University.

\section{A new encyclopedia on population}

Encyclopedia of Population

Paul Demeny and Geoffrey McNicoll, editors Macmillan Reference USA

The Encyclopedia of Population is the first comprehensive appraisal of the field of population studies in many decades. Edited by the Council's Distinguished Scholar, Paul Demeny (see above), and Policy Research Division senior associate Geoffrey McNicoll, the Encyclopedia is a testament to the broad scope and diversity of the population sciences. The nearly 300 contributors to the Encyclopedia represent a wide range of disciplinary backgrounds in the social, biological, and environmental sciences.

"In addition to its reference function, a test of such a work," according to Demeny and McNicoll, "is the extent to which it repays browsing and offers the reader serendipitous discoveries and insights." Thus the authors seek to make population issues and information accessible-and inter- esting - to a wide audience, including professionals, government and program managers, college students, and the educated lay reader.

Population issues often have been defined narrowly, with an emphasis on rapid population growth and family planning. The Encyclopedia gives full coverage to such matters, but the editors have painted on a much broader canvas to include such issues as the diversification of family forms, new medical technologies affecting reproduction and longevity, new or resurgent infectious diseases, the movement for women's equality and reproductive rights, populationrelated environmental change, and the evolutionary bases of demographic behavior. Important ethical debates related to population are also treated-longstanding issues such as asylum-seeking and equity between generations, and emerging issues such as genetic engineering and animal rights.
Momentum is a semi-annual newsletter of the Population Council. Information may be reproduced without permission, provided it is distributed free of charge and the source is acknowledged.

Writer

Editor

Copyeditor

Designers

Suzie Elliott

Ruth Kalla Ungerer

Robert Heidel

Y. Christina Tse

Mike Vosika

$50 \underset{1952-2002}{Y \text { EARS }}$

P.Population Council

One Dag Hammarskjold Plaza

New York, NY 10017

phone: 212-339-0500

fax: 212-755-6052

e-mail: pubinfo@popcouncil.org

http://www.popcouncil.org

REGIONAL OFFICES

South and East Asia: New Delhi, India

West Asia and North Africa: Cairo, Egypt

Sub-Saharan Africa: Accra, Ghana

Latin America and the Caribbean:

Mexico City, Mexico

The Population Council is an international, nonprofit, nongovernmental organization that seeks to improve the well-being and reproductive

health of current and future generations around the world and to help achieve a humane, equi-

table, and sustainable balance between people

and resources. The Council conducts biomedical,

social science, and public health research and

helps build research capacities in developing

countries. Established in 1952, the Council is

governed by an international board of trustees.

Its New York headquarters supports a global

network of 20 regional and country offices.

ISSN 1535-0525

(C) 2003 The Population Council, Inc.

Printed in the USA on recycled paper

Photos courtesy of staff photographer Karen

Tweedy-Holmes and other Council staff.

If you prefer to receive upcoming

Momentum editions online, please e-mail

us at pubinfo@popcouncil.org.

\section{Meetings in Africa}

continued from page 3

Reflecting on the trip, Martin noted, "I was impressed by the extent to which the Population Council is helping answer tough questions about what works and what does not. It is a tribute to our multi-talented staff and their reputation for high-quality, objective, policy-relevant research that governments, nongovernmental organizations, and academia look to the Council for leadership in research and the development of cost-effective strategies to address some of the region's most intractable human development issues." 
$5 \bigcirc$ Y Y A A R S

1 Population Council

One Dag Hammarskjold Plaza

New York, New York 10017 USA

\section{NEWS FROM THE
POPULATION COUNCIL NEWS FROM THE
POPULATION COUNCIL}

\section{$\operatorname{LSIPE}$}

\section{Survey of Pakistani youth}

Working at the cellular and molecular level

Protecting newborns from HIV

Breastfeeding and HIV

A population scientist's odyssey

On the ground in sub-Saharan Africa

\section{Council scholar honored}

New board members elected

\section{Encyclopedia of population}

Donaldson returns to Council

\section{Alumni search \\ If you know a Council alum- former fellow, trustee, or staff member-who is not receiving Momentum, please e-mail us at: development@popcouncil.org.}

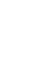

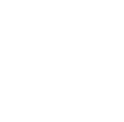

